\title{
Impact of Neo-Liberalism and Globalization
}

\author{
Ananda Majumdar \\ Researcher, Antarctic Institute of Canada, Canadian Aviation Tour 2017, University of Alberta, CANADA \\ *Corresponding Contact: \\ Email: anandamajumdar2004@yahoo.co.uk
}

\begin{abstract}
From the perspective of neoliberal globalization, the purpose of this essay is to explore and understand the social and educational phenomenon of student's migration from India to Canada, such as; Neoliberal globalization and its impact on higher education; Student mobility from India to Canada on their decision to pursue for higher studies; Indian and Canadian policies on international education and students; Factors Facilitating the success of overseas studies and the experience at the University of Alberta; Global Citizenship existence on international student. It is an expression of historical way of South American colonial, post-colonial, neo-colonial ideologies that are existed with present form of globalized and neo liberal ideologies to share thoughts within people all over the world but these present of universal thought, expression was not easy going in the past. However, a complete descriptions of ideologies which is active in present world order through deafening socialist ideologies. I would like to pursue my PhD in International Development and the ideas of liberalism, neo liberalism, colonialism, neo colonialism, globalization, will help me to understand global development by those ideologies. However, it has critical reviews, controversial thoughts but it has positive sides as well and I always prefer on positivism of globalization and neo liberalism through which world can be turns into one world order economically, I am hopeful.
\end{abstract}

Keywords: Economic Ideology, Globalization of Education, Canadian Liberal Government and Bill-C6, Economic Impact of International Education in Canada, Neo-Colonialism, Enlightenment

\section{INTRODUCTION}

Large number of international students who cross borders for the pursuit of higher education in recent years has been addressed and described by many schools and non-governmental organization. According to Canada Bureau of Education (CBIE), Canada ranks as the world's 7th most popular destination for international students and their enrolment grew from 159,426 in 2003 to over 290,000 in 2013 an $84 \%$ incensement. International students comprise $8 \%$ of the postsecondary student population in Canada. Canada derives $\$ 8 \mathrm{~B}$ annually from international student expenditures including tuition and living expenses and the presence of international students created over 83,000 jobs and generated over $\$ 291 \mathrm{M}$ in government revenue. There are top 5 countries of region, China, India, Korea, Saudi Arabia and France represent almost $60 \%$ 
total international student enrolment in Canada and Alberta represents $7 \%(20,380)$ international students from the world. From the perspective of neoliberal globalization, the purpose of this essay is to explore and understand the social and educational phenomenon of student migration from India to Canada.

\section{LITERATURE REVIEW}

Liberalism, Neo-liberalism, Globalization, Modernism, Global Governance, And Global Citizenship are ideologies that spread economic freedom through economic amalgamation between North and South Countries in the world. Economic freedom is connected with global economic development primarily through various international agreements such as GAT, NAFTA, ASEAN, and EU etc. and thus tried to make a one world to be focused on new commercial world order. As a result, developing countries opens their domestic market for foreign traders to invest in their countries infrastructure, health care and so on. It is due to globalization that education is in worldwide through distance learning, education exchange between countries, and student's exchange program between countries, international internship for educational and professional training. Globalization makes global students and global teachers, both are involved in a global academic institution, which makes them institutional citizen. NGO is an important example of neo-liberal globalization, they are going to the developing countries for development from developed world such as World Vision and thus world is now globalized, rural villages are going to role model in the field of educational development, economic self-sufficiently, and so on by the help of those NGO's which makes them to the point of local to global. Liberal policies inaugurated from western countries for economic development, cultural, educational, social, academic exchanges but it has several negative points such as it is a new form of control over third world countries economically at present world order. Economic competition or co-operation cannot be compared between developed and developing countries, developed countries are industrialized while developing countries are not; they are still agriculture-based economy while the world is running on industrial development swiftly and as a result developed countries are taking advantages through present world order. Academic, Cultural exchanges are good but students from developing countries are coming to the developed world and they are mostly forgetting their roots, their traditional values, they further cannot balance between their traditional culture and modern culture of developed countries. Therefore, economic trade pacts are good for developed countries because of foreign market investment but not as good for developing countries. Finally, I would say those ideologies have both negative and positive aspects especially through observation of European rule over Americas in eighteen and mid nineteen centuries, but yet those are important in the present world order for production, exchange, investment, peace and harmony, educational \& knowledgeable solidarity.

\section{Methodology}

As a Bachelor of Education after Degree student, I registered for a course Global Citizenship (INTD 404) a course under Educational Policy Studies faculty. I choose this syllabus topic as my term paper during the course development. I first choose the topic name through discussion with my instructor, after her approval, I started to collect information through electronic media such as websites, Wikipedia, and my course book Global Citizenship. I wrote three to four draft papers through various collection of information and thus knew the topic well; I made my final manuscript paper through the combination of my own thinking and collection of information over the topic and this paper is the result of my extensive research.

\begin{tabular}{|l|l|l|l|}
\hline Topic choose & $\begin{array}{l}\text { Approval by } \\
\text { Instructor }\end{array}$ & $\begin{array}{l}\text { Collection of } \\
\text { Materials through } \\
\text { electronic media }\end{array}$ & $\begin{array}{l}\text { Three to four times } \\
\text { writing draft about the } \\
\text { topic and the final draft }\end{array}$ \\
\hline
\end{tabular}




\section{Results AND Discussion}

Neoliberalism a globalized ideology, a return to an economic philosophy that grew out thinking of John Locke and Adam Smith. As neoliberalism thinking expanded during the second half of 20th century, globalization of the world economy resulted. Central to the philosophy of neoliberalism is free trade, and globalism. As a result, WTO changed with overseeing the implementation of global trading rule. WTO came into existence in 1995, replacing the General Agreement on Tariffs and Trade (GATT). GATT, IMF, WTO, OECD are new invention of neoliberalism and globalization is merely a new package for neoliberal ideology. As an ideology, it can be summarized as free-market individualism, private property and the minimal state. Neoliberalism has been expanded to the political, cultural, and ideological spheres. Therefore, Neoliberalism as a term has become the substitute of globalization in a particular set of policies for global governance. Globalization has been studied through different angles as a historical process through which inter-connectedness between national state and region has been strengthened through international economic-social and cultural intercourse and flows across the border. As per Robertson, who focused on the historical and social context of globalization distinguished three waves of globalization, first after 1500 which was globalization of regional trade, second after 1800 gained impetus from industrialization and the third was derived from a new world order after 1945. Liberalism, Neo-liberalism, Globalization, Colonialism, Post-Colonialism Neo-Colonialism, Clientisism, Populism, Barbarism, Welfare State, Welfare Economy are connected each other as western philosophical thought and words like liberalism, welfare state, historically came from the French revolution of the 1970 which discovered a word called enlightenment such as divine right, intellectual thinking, freedom, liberty, equality, fraternity, popular sovereignty against of the idea of monarchy and it's barbaric and traditional way of rule in Europe. These words established for the connection of people, countries, humanities, communication, exchanges through French and US revolution in the past and they are at present in the name liberal, neo liberal, globalized ideology. Colonialism was an expansion ideology of Spanish and Portuguese monarchy in the world and thus they established their rule in America, from Brazil to Mexico, Argentina to Guatemala, in every South American country in the name of exchanges, communication, global catholic education, however weakening of European countries through war each other influenced their rule in South American countries, it was already a curse because of their torture, inhuman barbaric behavior with indigenous Americans and the newly born creoles of Spanish generation in America tried to save their countries from European monarchy and to run by themselves. The result is freedom and the end of colonialism. Post Colonialism was the second ideology after colonialism where preference was given on industrialization of American countries and its progress by the building of railroad, telegraph cable, idea of export to other countries, building communication with other countries are all effort to establish a liberal thought and globalized idea with Europe and North America. Post-colonial economy was not for common people but for landlords and foreign investors and the fall of New York stock exchange in 1929 demolished this ideology and as the third ideology, Neo-liberalism discovered in American countries to establish government of their own people, end of slavery, and for the equality of all classes of people. Neo-Colonialism was another ideology of indirect rule by external powers and in nineteen centuries in the name of neo liberalism those South American countries suffered by new world powers through their gun boot policies, national doctrine policies and good neighbour policies and still now they are confused. Ideologies invented and established for liberty, equality, 
industrialization, but how much they gain from ideologies it is still questionable. Impact of globalization on higher studies flows in the third wave of globalization. The term neoliberal globalization is used because it has been embedded in globalization since 1950. Margaret Thatcher and Ronald Reagan propagated propositions of free market and free trade after 1980 and it is still impact on today's political, economic, and cultural system under the guise of globalizations, neoliberalism has become the dominant ideology and has been embraced by the countries all over the world. Neoliberal globalization is a significant challenge facing universities in this millennium. It is important to note, moreover, that responses of universities appear to differ according to the market economy, the strength of the economy and the willingness of the countries citizenry to pay enough taxes to bond public institutions. What is this challenge of neoliberal globalization for countries and how does it vary by market types? Spread of Access and Opportunities such as online education and the development of borderless universities offer increased to spread higher education to every corner of the world; increasing dangers and inequalities such as globalization as an economic process. According to George Soros, a prominent American financer, global capitalism is instable and for the democratization of transitional organizations. Indian students are in Canada for better education \& future in the report foreign student in Canada 2000-2010, Canada has experienced unprecedented growth in the number of foreign students in recent year. At the end of 2010, there were over 218,245 in total in the field of secondary or less, trade, university, other post-secondary and other foreign student in Canada rising from 114,093 in 2000 and 167,188 in 2005 from India. Economic impact of international education is very positive, international students spent around \$11.4 billion on tuition, accommodation and other spending in Canada as a result 122,700 jobs was created through their overall spending. In Alberta all kind of international students whether they are under graduate, graduate, high school, vocational, college studies spent $\$ 23,227$ million which is huge beneficial for Canada's economy. Canada receives the second most of its foreign student from India. There are number of Indo-Canadian educational organization in India such as Shastri Indo-Canadian Institute. The Shastri Indo-Canadian institute is a bi-national organization that promotes understanding between India and Canada through academic activities and exchanges. The institute creates bi-national links between academia, governments, the business community and civil society organizations by funding research and hosting seminars. This institute is one of the premium academic institutes for Indian students to explore Canada academically. Shastri Institute works with member institute throughout India and Canada who shares interest in internationalization and bi-national collaboration. In June 2011 SICI (Shastri Indo-Canadian Institute) along with Carleton University of Canada organized an educational meeting to increase more education co-operation, exchange program, commonwealth scholarship opportunities between India and Canada. Canada and India have MOU (memorandum of understanding agreement) in various fields, education is one of them, SICI is a prominent organization that complying this government's agreement for the highest stage of educational development, institutional development between two countries since 1968 by organizing various meeting in India and Canada where professors, chancellors of the universities of both countries participates for understanding each other and to find out areas of progress, research and higher education. Shastri Institute and the University of Alberta is member since 1977. University of Alberta and Tata Consultancy Services (TCS) has signed a five-year partnership agreement through which students can be provided internship and co-op education placements within TCS, to create research collaboration and exchange between university of Alberta and TCS researchers and expand India-Canada relations. India's policy on overseas study is to collaborate with 
Canada and Canadian academic institute in the field of science, technology, business and social science. It was very limited before 1990 because of India's stricter policies on overseas studies but in 1990, due to Open Door Policy and entering Free Market Economy by the three Governments of India; it became open to the students to go abroad for further studies and for a goal. It was a big influence to the society as an opportunity to study abroad. Current economic situation has impacted the recruitment of international student. With the influence of the global recession of 2008-09 on the Canadian post-secondary education, Usher and Dunn (2009) showed that the most immediate challenges facing the system are the decrease of institutional revenues and the increase of institutional costs. They suggested that one of the measures taken by governments to help institution survive the worst of the crisis could be increasing income from commercialization of activities. As an immigrant country, there is always a domestic demand for human resources. In recent years the Canadian Government realized that international students could be an excellent resource. By taking new measures like adjusting immigration policy and introducing offcampus work permits the Canadian Government intends to attract more international students who will stay in and contribute to the society. The Canadian Experience Class program introduced in 2008 for the settlement of international student in Canada permanently after following some requirements. The Conservative Government eased CEC requirements at the start of 2013. Foreign Students may stay in the country for up to three years following graduation giving them more time to gain the Canadian work experience needed to qualify for permanent residency. After three years of their permanent resident, they can apply for Canadian Citizenship. In 2015 there was changes in Canadian immigration policies by past conservative government by passing a bill called C-24, which made harder for international graduates of Canadian post-secondary programs to qualify for citizenship, the bill increased residency requirements after permanent residency from three to four years and eliminated applicant's ability to count half of their Canadian study time, up to one year. However new liberal government suggests a bill called C- 6 against of C-24 which will return all of those credits that exists before for international student, especially on their residency counts since their study in Canada from student to permanent resident. Those are the results of neoliberal policies that exist in present world order. It was Implications from Canada and India's policy towards higher education-social-cultural and academic rationales of recruiting international students can be observed in ISM from India to Canada. India's position on ISM from India to Canada has been shaped by the impact of neoliberal globalization on Indian society by the announcement of Open Door Policy (open communication in the field of business, academic with global north), economic reforms and entering WTO. The perspective of Indian students concerning their decision to pursue higher education in Canada is investigated through one of my Indian friend and communication with Indian Student Association at the University of Alberta. The question was what made you decide to come to Canada to pursue studies? I received various answer but the main was individual motivation that derived from cultural influence and personal worldview. The second type of motivation relates to employment pressures, the occupational demand for academic degree level and parental expectation. Factors facilitating the success of overseas studies: University of Alberta is home for academic successes. According to Indian Students Association (INDSA) and interview from my friend, the main factors facilitating the success of overseas studies are economic reason. All participants came to Canada with financial support from the University of Alberta in the form of doing research assistance or teaching assistance work. Socio-economic status of family also is a factor behind the success. Good family background will let parents understand why kids are willing to 
study abroad and they will support kids through their resources. My friend, Nitin Kundu, an Indian student said, University of Alberta offers many different programs in various faculties with great facilities and opportunities of co-op, research and industrial internship (he is doing his intern at Shell Canada). One of the best bets things about faculty of engineering is its common first year program which helps students learn about different engineering fields and make an education choice based on their potential interest. Students from India choose the University of Alberta 4 for some reasons such as; scholarships of undergraduate studies (IndiaU Alberta scholarship), graduate student funding (Atam Kapoor, an Indian graduate student won one of the prestigious scholarship \$50,000/year called Vanier doctoral scholarship). Dr. Manmohan Singh Award at the department of Economics for the top students and affordable tuition makes Indian student to come to Canada to accomplish their study abroad dream. Not only that various opportunities such as Teachers Assistance, Research Assistance are good job experience which cannot be found in India, many academic conferences, meetings, workshops are also part of Canadian education which attract them Indian student for their further studies and for their professional development. International students are global through participation of global communities at the University of Alberta. Global Citizenship concept has good deeds and bad deeds over international students, such as; Neo-liberal concept is a free movement in the world. GATT, WTO, IMF are all resulted of this concept which connects global south countries to global north countries. Globalization is undoubtedly producing a new civil society. Following Nigel Dower's global institution and global ethics, I can feel that international students are coming to Canada for their studies and participating is a global community through a member of global institution, which builds them institutional Citizen. Dower's Global Institution and Global Ethics are all approaches of neoliberalism concept connect neoliberalism ideology into global citizenship. The role of global educators and other allies in the conspiracy for global change, is to help weave of fabric of the new legend, key task is the creation of global consciousness and promotion of an ethos of global citizenship. International students are coming to Canada studying by renowned professors who are globally known for their teaching, passion and their learning citizenship education and thus students are promoted globally, they are doing research, jobs every corner of the world turns them global citizen. Global Citizenship Education has grown in its extent alongside understanding of the process of globalization. A neoliberal approach celebrates the dominance of a single global market and the principle of liberal transitional trade. From this perspective, a global citizen is one who is a successful participant in a liberal economy driven by capitalism and technology (Shultz, L. Educating for Global Citizenship, p 249). Thus neoliberalism, globalization related with global citizenship. India and Canada's national policies on overseas studies and on international students are also based on neoliberal globalism approaches through entering WTO, IMF, and GATT etc. India's free market policy, Canada's current liberal immigration process such as Canadian Experience Class immigration for foreigners in Canada is that example of connection with global citizenship concept. Understanding global citizen is a traveler. This citizen strives to create a place beyond traditional boundaries and local restrictions where he/she can access the political economic and environmental rewards of participation in a global society. International students are coming to Canadian institute as a traveler who are at the end globally recognized for their achievements and Canadian institutes are also globally recognized for its citizenship education through recruiting brilliant students around the world. Therefore, entire environments are related with global citizenship concept. International Education Program focuses on the recruitment of student from abroad. The Alberta Government fund and oversees an international education program that is part of its wider international relations policy. Focus on international education as a means to successful participation in global economy clearly indicated in recent policy that links such participation with the role of global citizenship. One of my discussions was Canadian policy on International students, those policies are driven by neoliberal approach and influenced on international student's community, which is linked with global citizenship approach, and therefore international students are global citizen. Through 
my readings on Professor Lynette Shultz's Neoliberal Citizenship and Transformational Citizenship what I understand that is Neoliberal Citizenship is a kind of citizenship where capitalism influences and transformational citizenship is a kind of citizenship where global north and global south are connecting by either non-profit organization such as Red Cross, Amnesty International etc. or any globally recognized institute such as the University of Alberta. International students are then both neoliberal and transformational citizen as they are already influences by those policies of the government, which builds on capitalism ideology, and they are the bridge between global north countries and global south countries exchanging their cultural images, knowledge and western education. Western education as a cultural imperialism in this sense that students from global south countries are coming to Canada and taking Western Knowledge have been influenced by Western Culture by participating night clubs, girlfriends, open relationships, freedom etc. International student is becoming global citizenship accepting western model due to their living in the western community, somehow they are forgetting their traditional culture. Justifying superiority and domination in this sense that Canada is proposing global education project through her attractive environment and worldview that is based on singular western dominated view to educational development to all global south students, which is Paternalism, ethnocentrism and hegemony. Colonization of knowledge in this senses that educating for Global Citizenship. Canada is recruiting foreign students following their policies on international students as a global education project. After learning western knowledge some students are going back to their countries and teaching their people through western knowledge which is good but is it creative to global south people? Are they able to accept it or understand it? Reproduce to legend in this sense that a legend shaped by patriarchy and colonialism driven by a free market forces of capitalism. The new version being offered is deeply troubling to many. Capitalism offers freedom, openness etc. that is sometime not good. International students are coming to Canada and most of them are not going back after finishing their studies, which is brain drain for their country. Good job, attractions, rewards, makes them too much interested on their host country and sometime affect students on their patriotism of their own countries. ISM should guide future studies in ISM. For instance, the impact of a culture of credentialing and the economic rationalizations imperative for ISM must be considered. Economic rationalizations should not be only motivator for overseas academic degrees, as the role of education should lie in its contribution to the cultivation of human beings and a society that does not simply exist to serve certain privileged social classes while succumbing to economic reductionism and the blind pursuit of individual freedom.

\section{Conclusion}

This essay focused on international students (primarily from India) perspective on pursuing their education in Canada within the perspective of neoliberal globalization. Generally, a key point rises that "What knowledge is of most worth and how far can we be sure that the knowledge acquired by students in the north is applicable to the context to which they may return in the south?" Indian economy is growing and students are going back to India from Canada after finishing their studies, so this question is important in Indian conservative environment. Students are coming from India and rest of the world to Canada for higher studies and brighter future, few students are going back their countries who have their own business back home or any source of property that they need to go back but once they stay in western world such as Canada, they used to take western culture, western liberal education and experience, when they go back their countries sometime they feel difficulties because of traditional culture and closed society as a result yet a western educated, they sometime did not achieved social status that they expected from their back home country because of cross cultural differences. However, they finally able to make a bridge between North and South countries and thus term of neo liberalization, modernism, and globalization exists due to their global citizenship status. Student exchange between countries are the result of current world 
order that is running by western thought of liberalism, globalization. Thus, I explored an experiment on student migration from countries to countries such as India and Canada vice versa for their brighter future and higher education and research and it is possible through current form of neo liberalism, globalization ideologies. Global Citizenship may be a problematic word to understand clearly because of its controversial sides discussed by scholars but though admitting into world universities from anywhere in the world can make us institutional global citizen and I have this award from the University of Alberta. Can I deny this term of global citizenship? I cannot deny but try to focus on its positivity's and present into communities and societies to know more.

\section{REFERENCES}

Canada India Education Council. (2015). International enrolment in Canada increases by $10 \%$ from 2013 to 2014. Toronto, Canada. Retrieved from http://canadaindiaeducation.com/internationalenrolment-in-canada-increases-by-10-from-2013-to-2014/

Chasteen, J. C. (2001). Born in blood and fire: A concise history of Latin America. New York: Norton

Department of Global Affairs Canada. (2016). Economic impact of international education in Canada - 2016 Update: 2016. Retrieved from http://www.international.gc.ca/education/reportrapport/impact-2016/index.aspx?lang=eng.

Dower, N., \& William, J. (2002). Global citizenship and critical introduction, New York: NY Routledge, p30

Kachur, J. (2008). Human rights imperialism: Third way education as the new cultural imperialism. In Abdi. A, \& Shultz. L., (Eds.), Educating for human rights and global citizenship New York: Sunny. P251

Odin, J., \& Manicas, P. (2004). Globalization and higher education. Retrieved from http://books.google.ca/books/about/Globalization_and_Higher_Education.html?id=GE_o85o LetQC.

Pike, G. (2008). Reconstructing the legend: Educating for global citizenship. In Abdi. A, \& Shultz. L., (Eds.), Educating for human rights and global citizenship. New York: Palgrave. p226

Roundtable Discussions: India-Canada collaboration in higher education - the road ahead. (2013, February). Shastri Indo-Canada institute newsletter. Retrieved from http://www.sici.org/news/article/roundtable-discussions-india-canada-collaboration-inhigher-education-the-r/.

Shultz. L. (2007). Educating for Global Citizenship conflicts, agendas and understanding. Alberta journal of education research, v53, n3, p249.

Shultz. L. (2007). Educating for global citizenship conflicts, agendas and understanding. Alberta journal of education research v53, n3, p251.

Sornarajah, M., \& Wang, J. (2010). India-China and the international economic order. Retrieved from http:/ /assets.cambridge.org/97805211/10570/frontmatter/9780521110570_frontmatter.pdf.

University Affairs.2016. Canadian government signals renewed openness to international students. Ottawa, Canada. Retrieved from http://www.universityaffairs.ca/news/newsarticle/canadian-government-signals-renewed-openness-international-students/.

Usher, A., \& Dunn, R. (2009). On the brink: How the recession of 2009 will affect post-secondary education. Toronto, ON: Educational policy institute. Retrieved from http//www.educationalpolicy.org

Zheng, J. (2010). Neoliberal globalization, higher education policies and international student flows: an exploratory case study of Chinese graduate Student Flows to Canada, special issue, Vol.2, 216-243. Retrieved from http://www.japss.org/upload/8\%20-\%20japss\%20zheng.pdf.

$$
--0--
$$

